\title{
anemon
}

Muş Alparslan Üniversitesi Sosyal Bilimler Dergisi

Journal of Social Sciences of Muş Alparslan University

Yı//Year: 2017 • Cilt/Volume: 5 • Sayı/Number: 3

ISSN: 2147-7655 • e-ISSN: 2149-4622

ÖZGÜN ARAŞTIRMA ○ ORIGINAL ARTICLE

\section{Teknoloji Entegrasyonu İçin Gerçekleştirilen Mesleki Gelişimin Kara Kutusunun İncelenmesi ${ }^{\text {a }}$}

\author{
Özden ŞAHIN IZMMIRLI ${ }^{1, b}$, Serkan İZMIRLI I ${ }^{1}$, Ömer KIRMACI ${ }^{2}$ \\ ${ }^{1}$ Yrd. Doç. Dr., Çanakkale Onsekiz Mart Üniversitesi, Eğitim Fakültesi, Çanakkale-Türkiye \\ ${ }^{2}$ Uzman, Kırklareli Üniversitesi, Uzaktan Eğitim Uygulama ve Araştırma Merkezi, Kırklareli-Türkiye
}

Başvuru tarihi: 28 Mart 2017 Düzeltme tarihi: 08 Mayıs $2017 \quad$ Kabul tarihi: 29 Mayıs 2017

\section{Öz}

$\mathrm{Bu}$ çalışmanın amacı, öğretmenlere yönelik teknoloji entegrasyonu için gerçekleştirilen bir mesleki gelişim etkinliğinde karşılaşılan zorluklar ve bu zorlukların aşılmasına yönelik alınan kararların yapılan planlama ile karşılaştırılarak betimlenmesidir. Nitel olarak desenlenen araştırmanın katılımcılarını teknoloji entegrasyonu mesleki gelişim etkinliğini gerçekleştiren 11 kişilik proje ekibi oluşturmaktadır. Proje ekibinden açık uçlu soru formları ve araştırmacı günlükleri ile veriler toplanmıştır. Araştırmanın bulgularına göre, katılımcıların süreçte zorluklarla karşılaştıkları planları şunlardır: Eğitimi uygulama okulunda gerçekleştirme, tüm öğretmenlere aynı anda eğitimlerin verilmesi, aynı branş öğretmenlerini aynı grup çalışmalarına alma ve öğretmenlerin kendilerinin istediği bu eğitimlere motive olmaları. Araştırma sonuçlarının teknoloji entegrasyonuna yönelik planlanacak ve gerçekleştirilecek mesleki gelişim etkinliklerinde nelere dikkat edilebileceğine yönelik uygulayıcılara önemli çıkarımlar sağlayacağı düşünülmektedir.

\section{Anahtar Kelimeler}

Teknoloji Entegrasyonu, Mesleki Gelişim Etkinliği, Zorluklar

\footnotetext{
a Bu çalışma, 114K977 nolu TÜBITAK projesi ürünüdür ve 16-18 Mayıs 2016 tarihlerinde Rize'de düzenlenen 10. Uluslararası Bilgisayar ve Öğretim Teknolojileri Sempozyumu'nda bildiri olarak sunulmuştur.

b Sorumlu Yazar/Correspoding Author: Çanakkale Onsekiz Mart Üniversitesi, Anafartalar Kampüsü, Eğitim Fakültesi, Bilgisayar ve Öğretim Teknolojileri Eğitimi Bölümü, 17100, Çanakkale/Türkiye. e-posta: osahinizmirli@gmail.com
} 


\section{Exploring the Black Box of Professional Development for Technology Integration}

\section{Abstract}

The purpose of this study is to describe difficulties faced and decisions made for overcoming these difficulties by comparing with planning made in a technology integration professional development activity for teachers. Participants of this qualitative research are 11 project members who worked in technology integration professional development activity. Data was collected through openended question forms and researcher diaries. According to research findings, participants' plans that faced difficulties are as follows: Conducting education in teachers' school, training teachers simultaneously, grouping teachers according to their branches, and being motivated to education activities that teachers participated in voluntarily. It is thought that research results provide important implications about what to consider in planning and conducting a professional development activity for practitioners.

\section{Keywords}

Technology Integration, Professional Development Activity, Difficulties

\section{GÍRİ̧̧}

Teknolojinin eğitimde kullanılmasının, yeni bir durum olarak görülmesi doğru olmayacaktır. Ancak günümüz bilgi toplumunda teknoloji kavramı bilgisayar ve iletişim teknolojileri (BİT) ile özdeşlemektedir. Bilgisayar teknolojilerinin ilk çıkış zamanlarından bu yana sürekli gelişmesi ve kendini yenilemesi, bu teknolojilerin öğrenme ve öğretme faaliyetlerine entegrasyonu yaklaşımlarının da sürekli değişmesini sağlamıştır (Cennamo vd., 2010; Mazman ve Usluel, 2011; Minor vd., 2013). Örneğin bilgisayarın ilk ortaya çıkış zamanlarında, başı başına kendisinin bir araştırma konusu olduğu görülmektedir. Günümüzün BİT entegrasyonu anlayışı ise bilgisayar ve teknoloji okuryazarlığının geliştirilmesi ve eğitim-öğretim faaliyetlerinde verimli bir şekilde kullanılması olarak göze çarpmaktadır.

Entegrasyon sürecinin tanımlanması konusunda alanyazında çok farklı yaklaşımlar bulunmaktadır. $\mathrm{Bu}$ yaklaşımlardan birisi BİT'in bireylerin günlük yaşamına ve okul kültürüne kazandırılması şeklindedir (Ogle vd., 2002). Diğer bir yaklaşım ise öğretmenlerin, öğrenme ve öğretme faaliyetlerini daha etkili ve verimli kullanabilmesi adına teknolojinin kullanımının sağlanması (Lim, 2007) ya da öğrencilerin teknoloji becerilerini daha verimli kullanabilmeleri için ortamların uygun hale getirilmesidir (Dockstader, 1999). Bu gibi yaklaşımlardan yola çıkarak teknoloji entegrasyonuna yönelik model oluşturma çalışmaları göze çarpmaktadır. Bu çalışmaların bazıları teknoloji entegrasyonunu kurum bağlamında, bazıları öğrenci ve öğretmen bağlamında, bazıları sosyo-kültürel etkileşim bağlamında, bazıları ise süreç içerisinde yer alan öğelerin etkileşimi bağlamında incelemiştir (Mazman ve Usluel, 2011). Bazı çalışmalar kurumların ya da paydaşların bulundukları entegrasyon seviyelerinin belirlenmesine yönelik iken (Toledo, 2005) bazıları ise entegrasyon sürecinde atılması gereken adımları 
ortaya koymaktadır (Robyler, 2006). Bu çalışmalar BİT entegrasyonunun eğitim öğretime etki eden bütün unsurlarının göz önünde bulundurulması gerektiğini belirtmektedir. Diğer taraftan Uluslararası Eğitim Teknolojileri Topluluğu (ISTE) [International Society for Technology in Education] ise, teknoloji kullanım hedefleri bağlamında öğretmen, öğrenci, yönetici ve mentor için eğitimde teknoloji standartları oluşturmuştur (ISTE, 2015). ISTE belirlediği standartlarla günümüz öğrenci, öğretmen ve diğer eğitim öğretim paydaşlarından beklenen teknoloji entegrasyonu yeterliklerini belirlemiştir. Teknolojinin sürekli değişim içerisinde olmasının yanı sıra öğrenci ve öğretmenlerin de sürekli değişmesi teknoloji entegrasyonunun sınırlılıkları arasında yer almaktadır (Mazman ve Usluel, 2011). Bu nedenle entegrasyon süreci için en önemli amaç bireylerin ve kurumların teknolojiye en verimli bir şekilde adapte olabilmeleridir (Ogle vd., 2002). Teknoloji entegrasyonu sürecinde belirtilen bu geçişin sağlanması ve sürekliliğin oluşturulmasında mesleki gelişim etkinlikleri önemli rol üstlenmektedir. Ancak teknoloji entegrasyonu bağlamında mesleki gelişim etkinlikleri genelde bilgisayar kullanım becerilerinin geliştirilmesi olarak algılanmaktadır (Ogle vd., 2002). Pierson'a (2001) göre öğretmenler, teknolojinin pedagoji ve öğretim programı ile bağlantısını anlamalıdır ve öğretim programının uygulanması sürecinde teknolojinin sağladığı pratikliği, öğretim tekniklerine uygulamayı başarabilmelidirler. Ancak birçok ülkede teknolojiye çok pahalı yatırımların yapılmasına karşın öğretmenlerin mesleki gelişimlerine yeterli yatırımın yapılmadığı görülmektedir (Spector, 2001).

Teknoloji entegrasyonunu gerçekleştirmeye yönelik projeler incelendiğinde, altyap1 zenginleştirme aşamalarından mesleki gelişim etkinliklerine kadar harcanan miktarların ciddi boyutlara ulaştı̆̆ söylenebilir. Türk eğitim sisteminin büyük çaplı yatırımlarından birisi olan "Fırsatları Artırma Teknolojiyi İyileştirme Hareketi (FATIH)" projesinde toplam maliyetinin 8 Milyar TL civarında olduğu belirtilmektedir (Gazete Vatan, 2012; Radikal, 2012). Bu nedenle ülkelerin ekonomisi için de teknoloji entegrasyonunun maliyetli bir süreç olduğu söylenebilir. Eğitim toplumlar için önemli yatırım alanlarındandır. Ancak özellikle az gelişmiş veya gelişmekte olan ülkelerde, derslik ve öğretmen sayısının azlığı, sınıf mevcutlarının kalabalıklı̆̆ı gibi eğitimin temel sorunlarının devam ettiği durumlarda, teknoloji entegrasyonuna yapılan yatırımların gerekliliğinin tartışıldığı görülmektedir (Güven, 2012). Öte yandan bu teknolojik yatırımların çoğunluğunun altyapı ve teknolojik yeterlilik kalemlerine ayrılmış olması entegrasyon süreçlerinin diğer aşamalarının başarısızlığ 1 durumunda yatırımın boşa yapılması sorunlarını da gündeme getirebilmektedir (Kaya ve Usluel, 2011). Diğer bir ifade ile altyapıya ve teknolojik donanıma çok fazla önem verilmesi durumunda sürecin entegrasyon boyutunun geri planda kalması riski de düşünülmelidir (Dursun, Tanyeri ve Çuhadar, 2011). Örneğin Türkiye'de gerçekleştirilen FATïH projesi, alt yapı geliştirme projesine dönüşmesi sebebiyle eleştirilmektedir. Proje kapsamında öğrenci ve öğretmenlere dağıtılan tablet bilgisayarlar, sınıflara getirilen akıllı tahtaları tamamlayıcı rolü olan entegrasyon boyutunda eğitimlerin yetersiz kalması eleştirilerin kaynağını oluşturmaktadır (Adıgüzel vd., 2011; Gürol vd., 2012). Aynı zamanda teknoloji her geçen süre içerisinde kendini yenileyen bir yapıya sahiptir. Teknolojik altyapı ve donanımların güncelliğinin sürdürülmesi, teknolojinin gelişim hızıyla kıyaslandığında, mali giderlerin daha da büyüyeceği öngörülebilir. Karip (2007), bu konuda bilişim teknolojisi ürünlerinin genellikle 2-3 yıl içerisinde ekonomik ömrünü tamamladığını, yapılan yatırımları bu 
yönüyle düşünülmesi gerektiğini belirtmiştir. Bu çerçevede insana yapılacak yatırımların önemi ortaya çıkmaktadır.

Öğretmenlerin teknoloji entegrasyonunu gerçekleştirilebilmeleri için onlara gerekli altyapı imkânlarının sunulması ve bu imkânların sürekli iyileştirilmesi gerekliliğinin yanı sira (Becker, 2000; Bingimlas, 2009; Kaya ve Usluel, 2011), teknoloji entegrasyonunu nasıl gerçekleştirebileceklerine yönelik bilgi ve becerileri edinmeleri için firsatların verilmesi (örn. Mesleki gelişim etkinlikleri) (Kaya ve Usluel, 2011; Hew ve Brush, 2006) gerektiği de belirtilmektedir. $\mathrm{Bu}$ noktada dikkatler öğretmenlerin teknoloji entegrasyonuna yönelik mesleki gelişim etkinliklerine yönelmektedir. Öte yandan bu eğitim etkinliklerinden beklenen değişimler ve gelişimlerin sağlanabilmesi için titizlikle planlanması, uygulanması ve değerlendirilmesi de gerekmektedir (Newby vd., 2000). Bu çerçevede düzenlenmiş mesleki gelişim etkinliği süreci planlamasının, etkinlik sürecinde yaşanan sorunların ve hatta bu sorunların nasıl aşıldığına dair deneyimlerin paylaşılması; gerçekleştirilecek yeni etkinliklere 1şık tutacaktır. Mesleki gelişim etkinliklerinin amacına ulaşıp ulaşmadığına ya da sonuçlarının nasıl olduğuna yönelik değerlendirme çalışmaları incelendiğinde bu çalışmaların sıklıkla eğitim alanlarla (öğretmenler) gerçekleştirildiği görülmektedir. $\mathrm{Bu}$ araştırmaların sonuçları incelendiğinde ise katılımcıların memnun kaldığ 1 (Kabaca vd., 2010), mesleki gelişim etkinliklerinin amacına ulaştı̆̆ (Uslu ve Bumen, 2012), yaygınlaştırılması gerektiği veya sürdürülebilirliğinin sağlanmasına yönelik önerilerin olduğu (Kabaca vd., 2010) sonuçları dikkat çekmektedir. Bu sonuçlar mesleki gelişim etkinliklerinden yararlananların penceresinden sürecin değerlendirilmesi açısından değerlidir. Mesleki gelişim etkinliği sürecinin değerlendirilebileceği ya da eleştirel analiz edilebileceği bir diğer pencere ise bu eğitimleri veren ekibin gözü olabilir.

Bu çalışmanın amacı, öğretmenlere yönelik teknoloji entegrasyonu için gerçekleştirilen bir mesleki gelişim etkinliğinde karşılaşılan zorluklar ve bu zorlukların aşılmasına yönelik alınan kararların yapılan planlama ile karşılaştırılarak betimlenmesidir. Araştırmanın verileri mesleki gelişim etkinliğini düzenleyen kokpitteki proje ekibinden toplandığı için bu süreçte mesleki gelişim etkinliği uçağının kara kutusu içerisinde olup bitenler gün ışığına çıkacaktır. Mesleki gelişim etkinliği katılımcıları sürecin kendileri için ne kadar yararlı olduğu ile ilgili fikir verebilirken, etkinliği düzenleyenler ise program hedeflerine ne kadar ulaştıklarını eleştirel gözle ortaya koyabilirler. Bu araştırmanın, mesleki gelişim etkinliği düzenleyecek ekiplere süreci planlama ve uygulama aşamalarıyla ilgili önemli çıkarımlar sağlaması beklenmektedir.

\section{ALANYAZIN TARAMASI}

Öğretim etkinliklerine teknolojiyi entegre etme ya da teknoloji entegrasyonu sürecinin daha verimli gerçekleşmesi için ulusların öğretmenler için mesleki gelişim etkinlikleri düzenledikleri görülmektedir. Gerçekleştirilen bu mesleki gelişim etkinliklerine yönelik çalışmalar incelenirken, sürecin kuramsal ve uygulama boyutlarında nasıl planlandığı, etkinliğin neyi hedeflediği, nasıl sonuçlara ulaştığı ve bu etkinliklerde katılımc1 motivasyonunun nasıl sağladığı gibi konulara odaklanılmıştır. Öğretmenlerin öğretim etkinliklerine teknolojiyi entegre etme süreçlerine yardımcı olunması amacıyla yürütülen mesleki gelişim etkinliklerinin uygulama ağırlıklı yürütüldüğünde daha başarılı olduğu 
görülmektedir (Liu vd., 2015; Peeraer ve Petegem, 2012; Plessis ve Webb, 2012; Uslu ve Bumen, 2012). Uygulama ağırlıklı yürütülen bu etkinliklerde farklı yöntemlerin denenmesinin de (örn. işbirliği ortamlarında öğrenme, mikro öğretim, mentor-menti öğrenme süreci vb.) süreci olumlu etkilediği görülmektedir (Liu, 2013; Liu vd., 2015; Unger ve Tracey, 2013). Uygulama ağırlıklı gerçekleştirilen bu mesleki gelişim etkinliklerinde eğitim içeriklerinin ise sadece teknolojilerin nasıl kullanılacağı üzerine olmadığı görülmektedir. Hatta teknolojinin nasıl kullanılacağıyla ilgili içeriklerinin yoğun olmadığı bunun yerine pedagoji, teknoloji entegrasyonun ne olduğu ve nasıl gerçekleştirilebileceğine dair uygulamaların sunulduğu görülmektedir (Kadijevich, 2012; Liu vd., 2015; Peeraer ve Petegem, 2012). Bazı mesleki gelişimi etkinliklerinde ise teknoloji entegrasyonuna yönelik etkinliklerin yanı sıra ders planlarının oluşturulması aşamasına da yer verilmesi gerektiği belirtilmektedir (Liu, 2013; Peeraer ve Petegem, 2012). Bunların yanı sıra teknoloji entegrasyonunun diğer paydaşlarından olan okul yöneticilerin de eğitim etkinliklerine katılmaları ve okul yönetiminin teknoloji entegrasyonunu desteklemesi öğretmelerin motivasyonunu ve teknoloji entegrasyonu süreçlerini olumlu yönde etkilemektedir (Liu, 2013; Tondeur vd., 2015). Okul yöneticisi ve öğretmenin teknoloji entegrasyonuna yönelik ortak katılacağ etkinliklerinin kurum vizyonunu geliştireceği belirtilmektedir. Böylece kurum vizyonunun gelişmesiyle, teknoloji entegrasyonuna yönelik bazı engeller mesleki gelişim etkinlikleriyle aş1labilecektir (Kopcha, 2012). Öğretmen motivasyonunu etkileyen bir diğer durumun ise öğretmenin öğrenmek için geldiği şeyi öğrenerek mesleki gelişim etkinliğini tamamlamasıdır (Unger ve Tracey, 2013; Wang vd., 2014). Diğer bir ifade ile yalın içeriklerin, doğrudan amaca yönelik anlatım ve uygulamaların gerçekleştirilmesinin, mesleki gelişim etkinliklerine katılan öğretmenler için önemli olduğu görülmektedir (Wang vd., 2014). Öte yandan teknolojiye dayalı mesleki gelişim programları planlanırken öğretmenlerin sorumlu oldukları içerik ve kapsam ile doğrudan ilgili içeriklerin sunumunun süreç motivasyonunu ve sürdürülebilirliği etkilediği belirtilmektedir (Unger ve Tracey, 2013). Bu faydacı yaklaşımın yanı sıra sürecin kuramsal dayanaklarının olması, öğretmenler tarafından bire bir fark edilen bir durum olmamasına rağmen, süreci disipline etmesi ve amaca yönelik uygulamaları desteklemesi açısından öğretmenleri motive edebilen gizil unsur olabileceği anlaşılmaktadır. Ayrıca mesleki gelişim etkinliklerinde alınan kararların ya da etkinliklerin kuramsal bir dayanağa oturtulması durumunda öğretmenlerin teknolojiyi sınıflarında kullanma eğilimlerinin de arttığı belirtilmektedir (Murthy vd., 2015; Peeraer ve Petegem, 2012). Öğretmeni süreçte motive eden kaynaklardan bir diğeri ise öğretmenin deneyimlerini paylaşabileceği ortamların olması, bu ortamlarda öğretmenin deneyimlerini paylaşması ve bu deneyimlerine ilişkin tartışmalar gerçekleştirmesi olarak belirtilmiştir (Peeraer ve Petegem, 2012; Tondeur vd., 2015). Dikkat edilen bu gibi durumlar süreci olumlu etkilemektedir. Öğretmenlerin yöneticileri tarafından takibinin gerekli olduğu (Guskey, 2000) belirtilmekle birlikte, öğretmenlerin süreçte devamlı yöneticileri tarafından takip edilmelerinin ise öğretmenin stres düzeyini artırdığı için olumsuz etkilediği görülmüştür (Liu, 2013). Ayrıca süreçte veya sürecin tamamlanmasından sonra geribildirimlerle ya da daha farklı değerlendirme yaklaşımları ile mesleki gelişim etkinliklerinin değerlendirilmesinin başarıyı etkilediği belirtilmektedir (Yıldırım vd., 2015; Plessis ve Webb, 2012). Mesleki gelişim etkinliği sürecinin değerlendirilmesinin sürecin amacına 
hizmet etme durumunu artırdığı gibi öğretmenlerin teknoloji entegrasyonu boyutunda ise sınıfta teknolojiyi kullanma eğilimini artırdığı görülmektedir (Murthy vd., 2015).

Mesleki gelişim etkinliği sürecine katılmış öğretmenlerin birçoğunun katıldıkları bu eğitim etkinliklerinin devamını istedikleri ve sürdürülebilirliğinin sağlanmasını bekledikleri görülmektedir (Kabaca vd., 2010; Plessis ve Webb, 2012; Wang vd., 2014). Bu devamlılığın sağlandığı durumlarda öğretmenlerin eğitim etkinliklerinde teknolojiyi kullanma durumlarının da devam ettiği görülmektedir (Peeraer ve Petegem, 2012; Uslu ve Bumen, 2012). Teknoloji entegrasyonunun sağlanmasına yönelik mesleki gelişim etkinliklerinin devamlılığın sağlanabilmesi için bazı hususlar araştırmacılar tarafından önerilmektedir. Örneğin öğretmen zaman planlamasının iyi yapılması (Yıldırım vd., 2015) ve yüksek katılımcı oranlarına ulaşmanın gerçekleştirilen mesleki gelişim etkinliklerinin devamlılığı için önemli olduğu anlaşılmaktadır. Bu durumların aksine öğretmenin zaman stresi yaşaması, süreci sahiplenmemesi, teknolojik kaynaklara ya da desteklere ulaşamaması onun sürece tutunmasını olumsuz etkileyebilmektedir (Wang vd., 2014).

\section{YÖNTEM}

Araştırma nitel olarak desenlenmiştir. İlişkilerin, etkinliklerin, durumların veya materyallerin niteliğini inceleyen araştırmalar sıklıkla nitel araştırma olarak adlandırılmaktadır. Nitel araştırma; deneysel araştırmalarda olduğu gibi belirli bir denemenin etkilerini karşılaştırma ve tarama araştırmalarında olduğu gibi insanların tutum ve davranışlarını tanımlamadan ziyade belirli bir etkinlik veya durumda neler olduğuna ilişkin detaylı bir tanımlama içermektedir (Fraenkel vd., 2012). Bu araştırmada bir mesleki gelişim etkinliğinde karşılaşılan zorluklar ve bu zorlukların aşılmasına yönelik alınan kararların yapılan planlama ile karşılaştırılarak detaylı bir tanımlaması yapıldığından nitel araştırma yöntemi benimsenmiştir. Bu nitel araştırmanın verileri açık uçlu soru formu ve araştırmacı günlükleri aracılığıyla toplanmıştır.

\subsection{Bağlam ve Katılımcilar}

$\mathrm{Bu}$ araştırma bir TÜBİTAK projesi kapsamında gerçekleştirilmiştir. Ortaokul öğrencilerinin kitap okuma etkinliklerinin takibi ve değerlendirilmesi amaçlanan projede çevrimiçi bir sistem (KİTaS: Kitap Okuma Etkinliklerinin Çevrimiçi Takip ve Değerlendirme Sistemi) geliştirilmiştir. KİTaS sisteminin okula entegrasyon süreci ile ilgili Çanakkale ilinde bir devlet ortaokulunda 2014-2015 eğitim öğretim y1lı bahar döneminde gerçekleştirilen mesleki gelişim etkinliği bağlamında bu araştırma yürütülmüştür. Teknoloji entegrasyonu mesleki gelişim etkinliği gerçekleştirilecek ortaokulda Milli Eğitim Müdürlügü'nden gerekli izinler alındıktan sonra okul müdürü ile doğrudan iletişim kurulmuştur. Başlangıçta okul müdürünün de olumlu yaklaşımı ile sürecin planlandığı gibi geçeceği öngörülmüştür. Mesleki gelişim etkinliği için dönem başında okulda ilgili panolara mesleki gelişim etkinliğinin konusu, süresi ve bağlamı hakkındaki proje afişleri asılmıştır. Okuldaki sınıf rehber öğretmenleri bu konularda ayrıca yüz yüze bilgilendirilmişlerdir. Gönüllü olan 12 sınıf rehber öğretmeni eğitim almıştır. Mesleki gelişim etkinliği esnasında öğretmenlere PowerPoint sunusu 
kullanılarak etkileşimli bir sunum yapılmaya çalışılmış ve el broşürü dağıtılmıştır. Üç proje üyesi tarafından verilen eğitimde KİTaS'ın nasıl kullanılacağı, paydaş rolleri, uygulama çıktıları ve süreçte yapılacaklar olmak üzere dört başlık altında sistemin okula entegrasyonu sağlanmaya çalışılmıştır. Eğitimi verecek proje üyeleri de eğitim verecekleri konular, katılımcı profili (yetişkinler), eğitimin süresi, zamanı ve mekânı, eğitim esnasında hangi teknolojik imkânlara sahip olacakları konularında bilgilendirilmişlerdir. Mesleki gelişim eğitimlerinin tüm öğretmenlere aynı zamanda verilmesi planlanmıştır. Ancak süreçte bu şekilde eğitimlerin verilmesi sağlanamamış, birebir, ikili veya üçlü gruplar oluşturularak eğitimler verilmiştir. Ancak mesleki gelişim etkinliği sürecinde planlananların tamamı istenildiği gibi olmamış süreçte bazı zorluklarla karşılaşılmıştır. Bu araştırmada eğitim sürecinde karşılaşılan zorluklar ve bu zorlukların aşılmasına yönelik alınan kararlar eğitim etkinliklerini planlayan ve uygulayanların (proje ekibi) gözünden incelenmiştir.

Araştırmanın katılımcılarını teknoloji entegrasyonu mesleki gelişim etkinliğini planlayan, süreçte kararlar alan ve uygulayan 11 kişilik proje ekibi oluşturmaktadır. Katılımcıların sekizi erkek, üçü kadındır Bu ekipte yer alan üyelerin projedeki rolleri ve demografik bilgileri Tablo 1'de verilmiştir.

Tablo 1. Mesleki Gelişim Etkinliğini Düzenleyenlerin Projedeki Rolleri

\begin{tabular}{ll}
\hline Katılımcı & $f$ \\
\hline Alan uzmanı & 3 \\
Mesleki gelişim eğitmenleri & 3 \\
Öğretim tasarımcısı & 2 \\
Ölçme ve değerlendirme uzmanı & 1 \\
Programlama dilleri uzmanı & 1 \\
Proje yöneticisi & 1 \\
\hline
\end{tabular}

Alan uzmanı olarak süreçte rol alan proje üyelerinin hepsi erkektir. Bunlardan bir alan uzmanı (33 yaş), konu alan uzmanı olarak yer almıştır. Türkçe eğitiminde doktora düzeyinde eğitim almış olan alan uzmanı, Türkçe ders içeriklerinin ve kitap okuma sürecinin nasıl gerçekleștiği ve süreçte teknolojinin hangi durumlarda kullanılabileceğine dair katkıları olmuştur. İkinci alan uzmanı (34 yaş) Bilgisayar ve Öğretim Teknolojileri Eğitimi alanında yüksek lisans, üçüncü alan uzmanı ise (34 yaş) Bilgisayar ve Öğretim Teknolojileri Eğitimi alanında lisans mezunudur. Bu alan uzmanları ise proje ekibinin karar verdiği mesleki gelişim eğitim içeriklerinin oluşturmuşlardır. Mesleki gelişim eğitimlerini veren iki kadın (24 yaş) eğitmen, Bilgisayar ve Öğretim Teknolojileri Eğitimi alanında lisans, diğer eğitmen (31 yaş) ise Türkçe eğitiminde yüksek lisans mezunudur. Proje ekibinde öğretim tasarımcısı olarak yer alan iki öğretim tasarımcısı da (34 yaş, 58 yaş) erkek ve Bilgisayar ve Öğretim Teknolojileri Eğitimi alanında doktora düzeyinde eğitim almışlardır. Proje ekibinde KİTaS’ı kullanacak öğrencilerin kitap okuma durumlarını belirlemede ölçme ve değerlendirme uzmanının görüşlerine başvurulmuştur. Ayrıca mesleki gelişim etkinliklerinin amacına ulaşma durumlarının nasıl belirlenebileceği ile ilgili önerileri alınarak, süreçte hareket edilmiştir. Ölçme ve değerlendirme uzmanı olarak yer alan erkek katılımcı da (41 yaş) Ölçme ve değerlendirme eğitimi alanında doktora düzeyinde eğitim almıştır. Programlama dilleri uzmanı (34 yaş) Bilgisayar ve Öğretim Teknolojileri Eğitimi alanında lisans mezunudur 
ve KİTaS'ın üretim boyutunda çalışmıştır. Son olarak tüm sürecin koordinasyon, yönetim ve kararların alınması sürecinde çalışan proje yürütücüsü (33 yaş, kadın) Bilgisayar ve Öğretim Teknolojileri Eğitimi alanında doktora düzeyinde eğitim almıştır.

\subsection{Verilerin Toplanmas1}

Araştırmanın verileri açık uçlu soru formu ve araştırmacı günlükleri ile toplanmıştır.

\subsubsection{Açık Uçlu Soru Formu}

Araştırmacılar tarafından mesleki gelişim etkinliğinde planlananlar, süreçte karşılan zorluklar ve bu zorluklara ilişkin alınan kararların belirlenebilmesi için açık uçlu soru formu oluşturulmuştur. Geliştirilen açık uçlu soru formu uzman görüşü (mesleki gelişim etkinliği düzenleme deneyimi olan iki uzman ve bir ölçme değerlendirme uzmanı) sonrasında son halini almıştır. Açık uçlu soru formunda yer alan bazı sorular şunlardır: "Mesleki gelişim etkinliği süresince planlananlar ile uygulananlar arasında farklılıklar oldu mu? Bunları detaylı açıklar mısınız? (Eğer farklılıklar varsa) Bu farklılıklar nasıl çözüme kavuşturuldu?" ve "Bu mesleki gelişim etkinliği süreci tekrar baştan başlasa nelerin farklı yapılması gerektiğini düşünüyorsunuz?”. Araştırmanın katılımcıları olan proje ekibine eposta yoluyla açık uçlu soru formları gönderilmiştir. Katılımcıların tamamı soru formlarını yanıtlamışlardır.

\subsubsection{Araştırmacı Günlüğ̈̈}

Mesleki gelişim etkinliğinin eğitimlerini veren üç kişi araştırmacı günlükleri tutarak süreçte gözlemlediklerini not etmiştir. Bu üç kişi toplam 15 sayfalık araştırmacı günlüğü yazmıştır. Araştırma günlükleri kapsamında araştırmacılar süreçte planlanan durumların dışında bir durum yaşanması halinde notlar tutmuşlardır. Rutin sürecin işlediği durumlar araştırmacı günlüğü kapsamında ele alınmamıştır. Günlük tutma işlemi mesleki gelişim etkinliklerinin başlaması ile başlayıp, mesleki gelişim etkinliklerinin tamamlanması ile son bulmuştur. Araştırmanın amacıyla ilgili nitel veriler araştırmada kullanılmıştır.

\subsection{Verilerin Analizi}

Açık uçlu soru formu ve araştırma günlüklerinden elde edilen veriler içerik analizi ile analiz edilmiştir. İçerik analizinde birbirine benzeyen veriler belirli temalar çerçevesinde bir araya getirilir. İçerik analizinde önce nitel veriler kodlanır, ardından temalar bulunur, sonra kodlar ve temalar düzenlenir ve son olarak bulgular tanımlanır ve yorumlanır (Yıldırım ve Şimşek, 2006). Araştırmadan elde edilen veriler iki araştırmacı tarafından analiz edilmiştir. Analiz yapılırken süreçte araştırmacılar bir araya gelip kararsız ya da uyumsuz oldukları noktalarda görüş birliğine varmışlardır. 


\subsection{Geçerlik ve Güvenirlik}

Nitel araştırmalarda geçerlik, araştırmacının veriye dayalı çıkarımlarının uygunluğu ve doğruluğudur. Güvenirlik ise farklı zaman ve mekânda da bu çıkarımların tutarlı olmasıdır (Fraenkel vd., 2012). Bu araştırmada da geçerlik ve güvenilirliği sağlamada bazı önlemler alınmaya çalışılmıştır. Bu önlemler şunlardır: Açık uçlu soru formlarını yanıtlanmasından sonra netlik kazanmayan bazı durumların anlaşılabilmesi için katılımcılardan teyit alınmıştır. Araştırma bağlamı tanımlanmıştır. Araştırma veri toplama aracı olan açık uçlu soru formu geliştirilirken uzman görüşüne başvurulmuştur. Araştırmacı günlüğü tutularak veri toplama süreci kontrol edilebilir olmuştur. Bulgular sunulurken doğrudan alıntılarla desteklenmiştir. Gerçekleştirilen mesleki gelişim etkinliği ile ilgili gerekli izinler alınmış ve kurum anahtar kişisi olarak okul müdürü ile süreç planlanarak, onun onayı çerçevesinde işlemler sürdürülmüştür. Araştırmacılar öğretmenleri ve okul müdürünü daha önceden tanımamaktadır. Araştırmacılar kuruma dışardan katılımcı olarak katılmış ve kurum kültürünü bilmeden sürece başlamışlardır. Bu durum araştırmacıların süreci önyargısız bir şekilde yürütmelerini ve yorumlamalarını sağlamıştır. Ancak kurum kültürünün bilinmemesi nedeniyle sürecin sürekliliği ve mesleki gelişim etkinliklerine katılımın devamlılığını sağlamada bazı sorunlar yaşanmıştır. Bu durumların aşılmasında okul müdüründen yardım alınmıştır.

\section{BULGULAR}

Gerçekleştirilen araştırmada öğretmenlerin KİTaS’ı eğitime entegre etmeleri için onlara mesleki eğitim etkinliği sunan 11 kişilik ekibe süreçte yapmayı planladıkları etkinlikler, bu planları gerçekleştirmede zorlandıkları durumların olup olmadığı ve olası zorlukları aşabilmek için neler yaptıkları sorulmuştur. Planlanan her bir durum, planlanan bu durumla ilgili karşılaşılan zorluk ve bu zorluğun aşılması için alınan kararlar aynı satırda karşılaştırmalı olarak sunulmuştur. Böylece hem yaşanan sürecin hem de neden -sonuç ilişkisinin daha iyi anlaşılacağı düşünülmektedir. Araştırmada mesleki gelişim etkinliğinde planlanan durumlar Tablo 2'de verilmiştir.

Tablo 2. Mesleki gelişim etkinliği kapsamında hangi planlanan durumlarda zorluklar yaşanmış ve kararlar alınmıştır?

1. Eğitimi uygulama okulunda gerçekleştirme

2. Tüm öğretmenlere aynı anda eğitimlerin verilmesi

3. Aynı branş öğretmenlerini aynı grup çalışmalarına alma

4. Öğretmenlerin kendilerinin istediği bu eğitimlere motive olmaları

Eğitim etkinliklerinde yaşanan zorluklar ve alınan kararlar yapılan planlarla karşılaştırılarak aşağıda sunulmuştur. 


\section{1. "Eğitimi Uygulama Okulunda Gerçekleştirme" Planında Yaşanan} Zorluklar ve Alınan Kararlar

Araştırma katılımcıları, eğitimi uygulama okulunda gerçekleştirmeyi planlamışladır. Mesleki gelişim etkinliklerini gerçekleştirecekleri mekân planlamasının süreçte düşündükleri gibi sonuç vermediğini ve bir zorlukla karşılaştıklarını belirtmişlerdir. Katılımcıların mekan planları, karşılaştıkları zorluklar ve duruma ilişkin kararları Tablo 3’te verilmiştir.

Tablo 3. "Eğitimi Uygulama Okulunda Gerçekleştirme" Planında Yaşanan Zorluklar ve Alınan Kararlar

\begin{tabular}{|c|c|c|}
\hline Planlananlar & Zorluklar & Kararlar \\
\hline $\begin{array}{l}\text { a1. Eğitimi uygulama } \\
\text { okulunda gerçekleştirme }\end{array}$ & $\begin{array}{l}\text { b1. Okulda bir etkinlik ya } \\
\text { da uygulama olduğunda } \\
\text { eğitim ortamının } \\
\text { kullanılamaması } \\
\text { b2. Okul ders süreleri ile } \\
\text { sinırlı kalınması }\end{array}$ & $\begin{array}{l}\text { c1. Okul dışında } \\
\text { eğitimlerin verilmesi } \\
\text { c2. Birebir ya da küçük } \\
\text { grup etkinliklerinin } \\
\text { yapılması }\end{array}$ \\
\hline
\end{tabular}

Katılımcılardan biri, mesleki gelişim etkinliğine katılan öğretmenlerin okulunda mesleki gelişim etkinliklerini gerçekleştirme kararı aldıklarını şu şekilde belirtmişlerdir:

"Uygulama okulunda eğitim verme fikri birçok açıdan mantıklı duruyordu. Örneğin mekâna para vermeyecek ya da mekân planlaması için zaman harcamayacaktık. En önemlisi de ögretmenlerin aşina olduklarl, zaten geldikleri yerde yapacaktık ĕgitimi. Katılımın da böylelikle iyi olacă̆ını düşündük" (Öğretim tasarımcısı1, açık uçlu soru formu).

Gerçekleştirilen bu planlamada iki nedenden dolayı sorun yaşandığı belirtilmiştir. Bunlardan ilki, okulda düzenlenen etkinliklerde mesleki gelişim etkinliğinin düzenlendiği sınıfin da kullanılması durumunda kalınması olarak ifade edilmiştir. $\mathrm{Bu}$ durumu, araştırma katılımcılarından biri "Okulun gerçekleştirdiği ilk etkinlikte bizim mesleki gelişim etkinliğimiz iptal olmak zorunda kaldı" (Öğretim tasarımcısıl, açık uçlu soru formu)" şeklinde belirtmiştir. Diğer bir sorun durumu olarak, mesleki gelişim etkinliklerinin teneffüs araları gibi zamanlarda okul öğrencileri tarafından bölünmesinin sürecin akıcılığını bozduğu dile getirilmiştir. Bu durum şu şekilde ifade edilmiştir: "eğitim ortamı teneffüste olan öğrenciler tarafindan defalarca bölünüyordu, bazı öğrenciler öğretmenlerine bir şeyler söylemek istiyordu..." (2 nolu Araşstırmacı günlüğü 15.05.2015). Yaşanan sorunların aşılması için katılımcıların mesleki gelişim etkinliklerini okul dışında yapma kararı aldıkları görülmektedir. Bu kararı katılımcılardan biri,

"Sürece başlamıştık ve şuandan sonra mekân değişikliği bizim için neredeyse imkânsız... Bunun bir de bütçe planlaması var çünkü. Bundan sonra gerçekleştirilecek eğitimlerin kurum dişında olması tekrar düşünülebilir, ancak o zaman öğretmen katılımlarının da gözlenmesi 
gerekir... Ancak şuan gördüğüm durumda farklı bir mekânın gerektiği yönünde..." (Proje yürütücüsü, açık uçlu soru formu).

şeklinde açıklamıştır. Ancak katılımcılar bu kararı uygulayamamışlardır. $\mathrm{Bu}$ sebeple sorunun çözümü için bir karar daha almışlardır. Birebir eğitimler ya da küçük grup etkinlikleri ile sürecin daha verimli geçeceği belirtilmiştir. Buna ilişkin katılımcılardan biri:

"mekân planlaması bizim için ciddi sorun oldu. ... mekân değişstirmek ve okul dlşında mesleki gelişim etkinliklerini gerçekleştirmek istedik. Ancak bizim sadece dört duvar değil, teknolojik cihazlara da ihtiyacımız vardl. Böyle bir mekân bulmak daha zor. Ögrretmenler kendi bilgisayarlarını getirseler diye düşündük... Mesleki gelişim etkinliği başlamıştı, daha fazla ögretmen kaybetmekten endişe ettik. Çünkü onlara sürecin başında bunu vaat etmemiş ya da bunları beklediğimizi söylememiştik. Ë̆itim grupların küçültmek hatta bazı öğretmenlerle birebir etkinlikleri sürdürmek en doğrusu oldu bizim için..." (Öğretim tasarımcısı2, açık uçlu soru formu).

şeklinde görüşünü açıklamıştır. Bu uygulama ile sorun çözülmüştür.

\section{2. “Tüm Öğretmenlere Aynı Anda Eğitimlerin Verilmesi” Planında Yaşanan Zorluklar ve Alınan Kararlar}

Araştırma katılımcıları, mesleki gelişim etkinliklerinin tüm öğretmenlere aynı anda aktarılmasını planladıklarını belirtmişlerdir. Ancak süreçte planlarının çalışmadığını belirtmişlerdir. Buna ilişkin planlar, karşılaşıtıları sorunlar ve duruma ilişkin kararlar Tablo 4'te sunulmuştur.

Tablo 4. "Tüm Öğretmenlere Aynı Anda Eğitimlerin Verilmesi” Planında Yaşanan Zorluklar ve Alınan Kararlar

\begin{tabular}{lll}
\hline \multicolumn{1}{c}{ Planlananlar } & \multicolumn{1}{c}{ Zorluklar } & \multicolumn{1}{c}{ Kararlar } \\
\hline $\begin{array}{l}\text { a2. Tüm öğretmenlere } \\
\text { aynı anda eğitimlerin } \\
\text { verilmesi }\end{array}$ & $\begin{array}{l}\text { b3. Tüm öğretmenlere } \\
\text { uyan ortak vakit } \\
\text { bulunamaması }\end{array}$ & $\begin{array}{l}\text { c2. Birebir ya da küçük } \\
\text { gruplar halinde } \\
\text { eğitimlerin verilmesi }\end{array}$ \\
\hline
\end{tabular}

Proje yürütücüsü mesleki gelişim etkinlikleri başlamadan önce eğitimlerin tüm öğretmenlere aynı anda verilmesini planladıkların "Tüm öğretmenlere aynı anda eğitim vermek zaman, emek ve en önemlisi mekân zorluğu yaşamayı önleyecekti" (Proje yürütücüsü, açık uçlu soru formu) şeklinde belirtmiştir. Bu planlama öğretmenlerin ortak uygun vakitlerinin bulunamaması sebebiyle yaşanan zorluk olarak ifade edilmiştir. $\mathrm{Bu}$ duruma ilişkin katılımcılardan biri görüşünü "öğretmenleri bir araya getirmek o kadar zor ki, kimisinin dersi var, kimisi nöbetçi... Ders saatleri dışında zaten sıklıkla okulda olmuyorlar..." (Proje yürütücüsü, açık uçlu soru formu) şeklinde belirtmiştir. Süreçte yaşanan bu zorluğu aşabilmek için tek tek ya da kü̧̈ük gruplar halinde eğitimlerin verilmesi kararı alınmıştır. Bu duruma ilişkin, "eğitmenler olarak biz çok daha fazla 
yorulduk ama sanırım buna değdi...Küçük grup eğitimleri daha verimliydi, herkes ile birebir ilgilenilebiliyordu." (Eğitmen 1, açık uçlu soru formu) şeklinde görüş bildirilmiştir.

\section{3. “Aynı Branş Öğretmenlerini Aynı Grup Çalışmalarına Alma” Planında Yaşanan Zorluklar ve Alınan Kararlar}

Araştırma katılımcıları, mesleki gelişim etkinliklerini tüm öğretmenlere aynı anda aktaramayınca süreçte birebir ve küçük gruplar halinde eğitim etkinlikleri düzenlenmeye başlamışlardır. Birebir eğitimlerde bir sorun yaşanmamakla birlikte küçük gruplar oluşturulurken, aynı branştaki öğretmenler bir araya getirilmeye çalışılmıştır. Ancak süreçte bu planın çalışmadığı görülmüştür. Buna ilişkin planlar, karşılaşılan sorunlar ve duruma ilişkin kararlar Tablo 5 'te sunulmuştur.

Tablo 5. "Aynı Branş Öğretmenlerini Aynı Grup Çalışmalarına Alma” Planında Yaşanan Zorluklar ve Alınan Kararlar

\begin{tabular}{lll}
\multicolumn{1}{c}{ Planlananlar } & \multicolumn{1}{c}{ Zorluklar } & \multicolumn{1}{c}{ Kararlar } \\
\hline $\begin{array}{l}\text { a3. Aynı branş } \\
\text { öğretmenlerini aynı grup } \\
\text { çalışmalarına alma }\end{array}$ & $\begin{array}{l}\text { b4. Yaratıcılı̆̆ın olmaması } \\
\text { b5.Teknolojik bilgi } \\
\text { farkından dolayı } \\
\text { uyumsuzluk }\end{array}$ & $\begin{array}{l}\text { c3. Benzer teknoloji } \\
\text { bilgisine sahip kişiler ile } \\
\text { grupların oluşturulması }\end{array}$ \\
\hline
\end{tabular}

Katılımcılar, öğretmenlerden küçük gruplar oluştururken izledikleri yolu şu şekilde açıklamışlardır: "İlk aklımıza gelen aynı branş öğretmenlerini, eğitimler sırasında aynı gruba almaktı. Mantık basit, kendi uzmanlık alanlarında daha çok ortak dil konuşup yaratıcı uygulamalar yapabilirlerdi." (Alan uzmanı1, açık uçlu soru formu). Katılımcılar bu planlarını uygularken süreçte beklediklerinin aksine yaratıcı uygulamaların olmadığını belirtmişlerdir. $\mathrm{Bu}$ durumlara ilişkin katılımcılardan biri, “...öğretmenlerin olumsuz yönde birbirlerini etkileyebileceklerine şahit olduk...'Yok bu konuda bir şey yapamayız' gibi..." (Alan uzmanıl, açık uçlu soru formu) şeklinde görüş belirterek, bir öğretmenin diğer öğretmeni süreçte olumsuz etkileyerek yaratıcı düşüncelere engel olabileceğini dile getirmiştir. $\mathrm{Bu}$ durumun yanı sıra öğretmenler arasındaki teknolojik bilgi düzeyi farklılıklarından dolayı uyumsuzlukların yaşandığı da belirtilmiştir. Bu duruma ilişkin katılımcılardan biri, "Farklı teknolojik bilgi sahibi olanlar bir araya gelince, iyi olanlar sıkıldı, biraz geride olanlarda süreçten kopmaya başladı..." (Eğitmen 1, açık uçlu soru formu) şeklinde görüşünü ifade etmiştir.

Yaşanan bu zorlukların aşılmasına ilişkin katılımcılar bazı kararlar almışlardır. $\mathrm{Bu}$ çerçevede her iki zorluk durumunun da "benzer teknoloji bilgisine sahip kişiler ile grupların oluşturulması” ile aşılabileceği belirtilmiştir. Bu duruma ilişkin, “... Böylece farklı branşlar birbirine ilham kaynağı olduğu gibi teknolojik olarak iyi olanlar sıkılmıyor, biraz geride olanlarda süreçten kopmuyordu" (Ĕgitmen 1, açık uçlu soru formu) şeklinde katılımc1 görüşünü belirtmiştir. 


\section{4. "Öğretmenlerin Kendilerinin İstediği Bu Eğitimlere Motive Olmaları" Planında Yaşanan Zorluklar ve Alınan Kararlar}

Öğretmenler, mesleki gelişim etkinlikleri hakkında bilgilendirilmişlerdir. Bunun sonucunda sürece katılmaya gönüllü olan öğretmenlerle mesleki gelişim etkinliklerinin sürdürülmesine karar verilmiştir. Böylece bu eğitimi almak isteyenlerin, ortam şartlarını ve planlananları bildikleri ve isteyerek geldikleri için motivasyonlarının yüksek olacağı düşünülmüştür. Ancak araştırma katılımcıları süreçte planlarının çalışmadığını belirtmişlerdir. Buna iliş̧kin planlar, karşılaştıkları sorunlar ve duruma ilişkin kararlar Tablo 6’te sunulmuştur.

Tablo 6. "Öğretmenlerin Kendilerinin İstediği Bu Eğitimlere Motive Olmaları" Planında Yaşanan Zorluklar ve Alınan Kararlar

\begin{tabular}{lll}
\hline \multicolumn{1}{c}{ Planlananlar } & \multicolumn{1}{c}{ Zorluklar } & \multicolumn{1}{c}{ Kararlar } \\
\hline a4. Öğretmenlerin & b6. Birbirini tanıyan & $\mathrm{c} 4$. Yuvarlak masa \\
kendilerinin istediği bu & grubun bir araya gelince & oturma düzeni yerine \\
eğitimlere motive olmaları & sohbet etmeleri & «C» oturma düzeni \\
& b7. Motive edici & c5. Mesleki gelişime \\
& unsurların eksikliği & katılım için para \\
& & verilmesi \\
\hline
\end{tabular}

Okulda tüm öğretmenlere afişlerle ve tanıtım toplantıları ile gerçekleştirilmesi planlanan mesleki gelişim etkinliği tanıtılmıştır. Süreç ve yapılacaklar önceden öğretmenlere anlatılmıştır. Bu aşamadan sonra mesleki gelişim etkinliğine katılmaya gönüllü olan öğretmenlerle mesleki gelişim etkinliği sürdürülmüştür. Bu işlem adımlarından dolayı katılımcılar öğretmenlerin süreçte kendi istedikleri bu eğitimlerde motivasyonlarını kaybetmemelerini beklemişlerdir. Bu beklentilerini katılımcılardan biri şu şekilde açıklamıştır:

"Onlara sorulmuştu, bu eğitimi istemişlerdi, tamamen gönüllü katılmışlardl...Onlara süreçte neler yapılacağl, sürecin nasıl ilerleyeceği, neler ögrenecekleri, sorumluluklarının neler olduğu ve ne kadar süreceği hep anlatıldl... Ama şuan sanki bizim zorumuzla süreç işliyor... Diyorlar ki, ne çabuk bir hafta geçti... Aaa ben onu unutmuşum..." (3 nolu Araştırmac1 günlüğü 09.04.2015).

Katılımcılar öğretmenlerin motivasyon kayıplarının yaşandığı iki durumdan bahsetmişlerdir. Bunlardan ilki "birbirini tanıyan grubun bir araya gelince sohbet etmesi ve öğretmenler odasından da buna alışık olması" dır. Buna ilişkin katılımcılardan biri,

"Şimdi sorun ne, ne oldu anlayamadım. Etkinliklere kattliyorlar ama ev etkinliklerini yapmiyorlar. Sanki kendileri zamanında gönüllü oldukları için şimdi zorunlu geliyorlar... Kendi aralarında sohbet geliştirip ve buraya katılma amaçlarını unutmuş gibiler..." (Eğitmen2, açık uçlu soru formu). 
şeklinde görüşünü belirtmiştir. Diğer bir katılımcı ise;

“Birbirilerini tanıdıkları için azıcık bir boşlukta 'Nasılsın' diye hal hatır sorarak başlatılan bir sohbet gelişiyor, sanki ögretmenler odasindalar ve ders aralarında buluşmuş gibi bir ortam oluyor..." (Eğitmen3, açık uçlu soru formu)

şeklinde görüşünü belirtmiştir.

Öğretmenlerin motivasyon kayıpları yaşadıkları bir diğer durum ise;

"onlar motive edici unsurların eksikliği” olmuştur. Bu duruma ilişkin katılımcllardan biri, "onlar bu ĕgitimi istese de, mesleki gelişim etkinliği kısa sürmüyor, yaklaşık bir dönemlik bir etkinlik, okulda işleri var, idari sorumlulukları var, yoğunlar yani” (Eğitmen2, açık uçlu soru formu)

şeklinde görüşünü açıklamıştır.

Yaşanan bu durumlara ilişkin katılımcıların aldıkları kararlardan bazıları anlık çözümü sağlarken bazılarının ise bundan sonra gerçekleştirilecek çalışmalarda yapılabilecek durumlar olduğu görülmektedir. Katılımcılar, öğretmenlerin oturma düzenlerini değiştirerek mesleki gelişim etkinliklerine daha fazla odaklanmalarını sağlamaya çalışmışlardır. Bu duruma ilişkin katılımcılar, "grupları küçültüp, 'C' düzeni oturttuk. C'nin karşısında da eğitmen vardı. Ya da birebir eğitim etkinlikleri ile böyle bir durumu tamamen ortadan kaldırdık." (Eğitmen3, açık uçlu soru formu)" şeklinde durumu anlatmışlardır. Katılımcıların süreçte azalan öğretmen motivasyonuna ilişkin belirttiği bir diğer karar ise, "mesleki gelişim etkinliğine katılanlara bir miktar para ödenmesi" şeklinde olmuştur. Bu duruma ilişkin katılımcılardan biri,

"Kesinlikle bir daha eğitim planlanan bir projeye katılırsam, eğitim alanların para alacakları bir sistem talep ederim, bunun dünyada da örneği çok. Ben küçük çaplı bir eğitim ekibiyim. Eğitim sistemini değiştiremem, ögretmenlerin bu eğitimlere ihtiyaç duyacaklarl ortamları oluşturamam ya da ögretmenlerin günlük etkinlik planlarına müdahale edemiyorsam onlarl farkl kanallardan motive edebilirim. Bu bir miktar para ödemesi olabilir." (Proje yürütücüsü, açı uçlu soru formu)

şeklinde görüşünü açıklamıştır.

\section{SONUÇ VE DEĞERLENDİRME}

Teknolojinin eğitimde amacı, rolü ve yeri ne olmalıdır? Bu soruya "eğer şöyle olursa bu olur, eğer böyle olursa şu yapılır” diye bir tanım yapılamamaktadır. Kenarlarını düzeltip, köşelerini keskinleştirip "işte teknoloji entegrasyonunun şekli budur" denilememektedir. Biliyoruz ki, bu süreci etkileyen ve bu sürecin de etkiledikleri var. Alanyazında teknoloji entegrasyonunun sağlanması için öğretmenlere teknoloji entegrasyonunu nasıl gerçekleştirebileceklerine yönelik bilgi ve becerileri edinmeleri için firsatların verilmesi (örn. Mesleki gelişim etkinlikleri) (Kaya ve Usluel, 2011; Hew ve Brush, 2006) gerektiği 
belirtilmektedir. $\mathrm{Bu}$ etkinliklere öğretmenlerin katılmasının yanı sıra teknoloji entegrasyonu sürecinde ileriye yönelik adımlar atabilmek için mesleki gelişim etkinliklerinin amacına ulaşıp ulaşmadığına yönelik değerlendirmelerin önemi de ifade edilmektedir. $\mathrm{Bu}$ araştırmada öğretmenlere yönelik teknoloji entegrasyonu için gerçekleştirilen bir mesleki gelişim etkinliğinde karşılaşılan zorluklar ve bu zorlukların aşılmasına yönelik alınan kararların yapılan planlama ile karşılaştırılarak proje ekibi gözünden betimlenmesi amaçlanmıştır. Böylece bu çalışmada mesleki gelişim etkinliğine katılanların memnuniyet algılarının belirlendiği çalışmalara ek olarak sürecin daha işlevsel olabilmesi ya da benzer sorunların ileride yaşanmaması için uygulayıcı deneyimleri paylaşılmıştır.

Araştırmada bir okulun öğretmenlerine yönelik gerçekleştirilen mesleki gelişim etkinliklerinin düzenleneceği okuldaki bir sınıfın/toplantı odasının başka etkinlikler için de kullanılabildiği, okuldaki öğrenciler tarafından mesleki gelişim etkinliklerinin bölünebildiği gibi zorluklar belirlenmiş̦tir. Mesleki gelişim etkinliği gerçekleştiren ekip, bu zorlukların etkinliğin kurum dışında gerçekleştirilmesi ile aşılabileceğini ifade etmiştir. Araştırma katılımcılarının bu görüşünün alanyazınla çeliştiği görülmektedir. Alanyazında kurum dışında gerçekleştirilen uygulamaların bağlamdan kopuk olduklarından başarısız oldukları ifade edilmektedir (Clarke ve Hollingsworth, 2002; Desimone, 2009; Fullan, 2005; Guskey, 2000). Bu araştırmada proje ekibi mesleki gelişim etkinliğini kurumda gerçekleştirmiş ancak kurumda sorun yaşadıklarından dolayı bundan sonraki etkinliklerin kurum dışında yapılması kararını almışlardır. Bu çerçevede mesleki gelişim etkinliklerinin başarılı olabilmesi için kurumda yaşanan sorunların çözülerek kurumda gerçekleştirilmesi gerektiği söylenebilir. Kurumdan bağımsız bir yerde eğitim etkinliği düzenleyen kuruluşların sıklıkla bir okula değil daha kalabalık ekiplere eğitim verdikleri, büyük bütçelerle desteklendikleri de görülmektedir (örn. Fatih Projesi). Mesleki gelişim etkinliklerine öğretmenlerin yanı sıra okul yöneticileri de dahil edilerek kurum vizyonunun da geliştirilmesi hedeflenebilir (Liu, 2013; Tondeur vd., 2015). Böylece kurum yöneticilerinin de faydasına inandıkları bu etkinlikler, dış engellerden (öğretmen nöbetleri, öğrencilerin etkinlik alanına giriş çıkışı ve mekânın izolasyonu vb.) etkilenmemesi için korunabilir.

Araştırmada katılımcılar tarafından mesleki gelişim etkinliğine katılacak öğretmenlerin tamamı için uygun ortak zaman belirlenmesinin zorluğu dile getirilmiştir. Bu zorluğun aşılması için eğitim etkinliğinin daha küçük gruplara verilmesi ya da birebir eğitimlerle sürecin devam etmesi çözümleri sunulmuştur. Her ne kadar mesleki gelişim etkinliklerinin var olan sürecin yanında ya da mola sürelerinden çalarak paralel bir süreç olarak yürütülmesi normal gibi algılansa da, mesleki gelişim etkinliklerinin ayrı bir iş̧ kalemi olarak ele alınıp, kendisine ayrılan zaman ve mekânda sürdürülmesi gerektiği söylenebilir. Mesleki gelişim; okul iklimi, yöneticinin tutumu, yerel eğitim politikaları ve katılımcıların etkinliğin planlamasına katılma durumları gibi kurumsal bağlam faktörlerinden etkilendiği için (Sparks ve Loucks-Horsley, 1989) mesleki gelişim etkinliklerini okulda katılımcıların tamamının katılacağı şekilde planlamak kolay olmamış olabilir. Okulların mesleki gelişim uygulamaları yapılmasını destekleyen olan bazı normlara sahip olması beklenmektedir (Sparks ve Loucks-Horsley, 1989). Bu araştırmada uygulama gerçekleştirilmeye çalışılan okulun bu bağlamda normları olmayabilir ve bu durum tüm öğretmenler için aynı anda mesleki gelişim etkinliğini 
yapmayı zorlaştırmış olabilir. Ayrıca okul yöneticisinden mesleki gelişim etkinliğine katılan öğretmenlerden beklentilerini ifade etmesi, aktif olarak etkinliğe katılması ve öğretmenlerin çabalarını desteklemesi beklenmektedir (Sparks ve Loucks-Horsley, 1989). Bu araştırmada yöneticinin aktif olarak sürece katılmaması ögrretmenlerin toplu olarak etkinliğe katılamamasına neden olmuş olabilir. Mesleki gelişim için harcanan zaman, maliyet, iş gücü gibi değerler düşünüldügünnde tüm çabaların anlamlı olabilmesi için eğitim etkinlikleri için özel zamanlar ayrılması gerektiği ve zaman planlamasının dikkatli bir şekilde gerçekleştirilmesi gerektiği söylenebilir (Yıldırım, Kurşun ve Göktaş, 2015). Bu durumların alternatifi elbette birebir eğitimler olabilir. Lakin bu eğitimlerin yaygınlaştırılması ya da maliyeti düşünülerek planlanması gerektiği söylenebilir. Gerçekleştirilen bu araştırmada küçük gruplar halinde de eğitimler verilmiştir. Burada öğretmenlerin branşlarından ziyade teknoloji bilgi düzeyleri birbirine yakın olan grupların sürecin sürekliliğini daha iyi sağladıkları görülmüştür. Aksi takdirde iyi bilenin sıkıldığı, duruma göre geri kalanında süreçten kopabileceği belirtilmiştir. Teknoloji entegrasyonunu desteklemek üzere gerçekleştirilecek eğitim etkinlikleri gruplarının hangi kriterlere göre oluşturulabileceğine ilişkin araştırmalar desenlenebilir.

Araştırmada sürece gönüllü olarak katılan öğretmenlerin motivasyonlarının düştüğü, sürecin takibinde zorlandıkları belirtilmiştir. Hatta katılımcılar, öğretmenlerin gönüllü olarak katıldıkları bu süreçte kendileriyle çelişir şekilde süreçte motivasyonlarını kaybettiklerini belirlemişlerdir. Alanyazın incelendiğinde öğretmen motivasyonunu etkileyen durumlardan birinin de öğretmenin öğrenmek için geldiği şeyi öğrenerek mesleki gelişim etkinliğini tamamlaması olduğu görülmektedir (Unger ve Tracey, 2013; Wang vd., 2014). Birer yetişkin olarak öğretmenler öz yönelimli öğrenenlerdir. Dolayısı ile öğretmenlere yönelik bir mesleki gelişim etkinliği planlanırken onların öğrenme amaçları, gereksinimleri belirlenmelidir (Knowles, 1980). Bu araştırmada da öğretmenlerin gereksinimleri belirlenmiş ve etkinlik planlanmıştır. Ancak öğretmenlerin süreçte motivasyonlarının düşmesi çelişkili bir durumdur. Bu eğitim etkinliklerindeki dilin yalınlığı, içeriklerin doğrudan amaca yönelik sunumu ve uygulamaların gerçekleştirilmesinin, mesleki gelişim etkinliklerine katılan öğretmenler için önemli olduğu vurgulanmaktadır (Wang vd., 2014). Bu kapsamda gerçekleştirilen mesleki gelişim etkinliklerinin bu açılardan da incelenebileceği söylenebilir. Ayrıca öğretmeni süreçte motive eden kaynaklardan bir diğeri ise öğretmenin deneyimlerini paylaşıp, tartışabileceği ortamların olduğu belirtilmektedir (Peeraer ve Petegem, 2012; Tondeur vd., 2015). Bu noktada grup etkinlikleri ya da öğretmenlerin diğer meslektaşları ile iletişimlerinin önemi belirtilmektedir. Eğitim etkinliklerine katılan öğretmenlerin bu etkinlikler çerçevesinde katılımları onları motive edebilir ya da katılım yüzdelerini artırabilir. Ancak bu sonuca varmadan önce bu durumların da bilimsel olarak denenmesine ihtiyaç vardır.

\section{KAYNAKÇA}

Adıgüzel, T., Gürbulak, N., \& Sarıçayır, S. (2011). Akıllı tahtalar ve öğretim uygulamalar1. Mustafa Kemal Üniversitesi Sosyal Bilimler Enstitüsü Dergisi, 8(15), $457-471$. 
Becker, H. J. (2000). Findings from the teaching, learning, and computing survey. Education Policy Analysis Archives, 8, 51.

Bingimlas, K. (2009). Barriers to the successful integration of ICT in teaching and learning environments: A review of the literature. Eurasia Journal of Mathematics, Science \& Technology Education, 5(3), 235-245.

Cennamo, K. S., Ross, J. D., \& Ertmer, P. A. (2010). Technology integration for meaningful classroom use: A standards-based approach. Wadsworth, Cengage Learning, CA

Clarke, D., \& Hollingsworth, H. (2002). Elaborating a model of teacher professional growth. Teaching and Teacher Education, 18(8), 947-967.

Desimone, L. M. (2009). Improving impact studies of teachers' professional development: Toward better conceptualizations and measures. Educational Researcher, 38(3), 181-199.

Dockstader, J. (1999). Teachers of the 21 st century know the what, why, and how of technology. THE Journal, 26(6), 73-75.

Du Plessis, A., \& Paul, W. E. B. B. (2012). A teacher proposed heuristic for ict professional teacher development and implementation in the South African context. TOJET: The Turkish Online Journal of Educational Technology, 11(4).

Dursun, Ö. Ö., Tanyeri, T., \& Çuhadar, C. (2011). Bilgi toplumu kavramı: Türkiye perspektifinden bir bakış. 11th International Educational Tecnology Coference. Volume II. Istanbul, Turkey, 1367-1372.

Fraenkel, J. R., Wallen, N. E., \& Hyun, H. H. (2012). How to design and evaluate research in education (8th ed.). New York: McGraw Hill.

Gazete Vatan (2012). İşte Fatih Projesi'nin toplam maliyeti!. (Erişim: 02.01.2016), http://www.gazetevatan.com/iste-fatih-projesi-nin-toplam-maliyeti--452784ekonomi/

Gürol, M., Donmuş, V., \& Arslan, M. (2012). İlköğretim kademesinde görev yapan sınıf öğretmenlerinin fatih projesi ile ilgili görüşleri. Eğitim Teknolojileri Araştırmaları Dergisi. 3(3).

Guskey, T. R. (2000). Evaluating professional development. California: Corwin Press, INC.

Güven, İ. (2012). Eğitimde 4+4+4 ve Fatih Projesi yasa tasarısı=Reform mu?. Ilkögrretim Online, 11(3), 556-577.

Hew, K. F., \& Brush, T. (2006). Integrating technology into K-12 teaching and learning: Current knowledge gaps and recommendations for future research. Educational Technology Research and Development, 55(3), 223-252.

ISTE (International Society for Technology in Education) (2007). Differentiating Instruction with Technology in K-5 Classrooms. (Erişim: 02.01.2016), http://www.iste.org/images/excerpts/diffk5-excerpt.pdf 
Kabaca, T., Aktümen, M., Aksoy, Y., \& Bulut, M. (2010). Matematik öğretmenlerinin Avrasya GeoGebra toplantısı kapsamında dinamik matematik yazılımı GeoGebra ile tanıştırılması ve GeoGebra hakkındaki görüşleri. Turkish Journal of Computer and Mathematics Education (TURCOMAT), 1(2).

Kadijevich, D. M. (2012). TPCK framework: Assessing teachers' knowledge and designing courses for their professional development. British Journal of Educational Technology, 43(1), E28-E30.

Karip, E. (2007). İlköğretimde kalite: Avrupa Birliği kalite göstergeleri çerçevesinde kalitenin değerlendirilmesi. (Ed., Özdemir, S., Bacanlı, H., \& Sözer, M.), Türkiye'de okul öncesi eğitim ve ilköğretim sistemi temel sorunlar ve çözüm önerileri. Ankara: Türk Eğitim Derneği. 211-267.

Kaya, G., \& Usluel, Y. K. (2011). Öğrenme-öğretme süreçlerinde BİT entegrasyonunu etkileyen faktörlere yönelik içerik analizi. Buca Eğitim Fakültesi Dergisi, 31, 48-67.

Knowles, M. S. (1980). The modern practice of adult education: From pedagogy to andragogy. Cambridge: The Adult Education Company.

Kopcha, T. J. (2012). Teachers' perceptions of the barriers to technology integration and practices with technology under situated professional development. Computers \& Education, 59(4), 1109-1121.

Lim, C. P. (2007). Effective integration of ICT in Singapore schools: Pedagogical and policy implications. Educational Technology Research and Development, 55(1), 83116.

Liu, S. H. (2013). Teacher professional development for technology integration in a primary school learning community. Technology, Pedagogy and Education, 22(1), 37-54.

Liu, S. H., Tsai, H. C., \& Huang, Y. T. (2015). Collaborative professional development of mentor teachers and pre-service teachers in relation to technology integration. Journal of Educational Technology \& Society, 18(3), 161-172.

Mazman, S. G., \& Usluel, Y. K. (2011). Bilgi ve iletişim teknolojilerinin öğrenmeöğretme süreçlerine entegrasyonu: modeller ve göstergeler. Eğitim Teknolojisi Kuram ve Uygulama, 1(1), 62-79.

Minor, M., Losike-Sedimo, N., Reglin, G., \& Royster, O. (2013). Teacher Technology Integration Professional Development Model (SMART Board), Pre-Algebra Achievement, and Smart Board Proficiency Scores. SAGE Open, 3(2), 1-10.

Murthy, S., Iyer, S., \& Warriem, J. (2015). ET4ET: a large-scale faculty professional development program on effective integration of educational technology. Journal of Educational Technology \& Society, 18(3), 16-28.

Newby, T., Stepich, D., Lehman, J., \& Russell, J. (2000). Instructional technology for teaching and learning: Designing instruction, integrating computers, and using media. Educational Technology \& Society, 3(2). 
Ogle, T., Branch, M., Canada, B., Christmas, O., Clement, J., Fillion, J., Goddard, E., Loudat, N.B., Purwin, T., Rogers, A., Schmitt, C., Vinson, M. (2002). Technology in schools: Suggestions, tools and guidelines for assessing technology in elementary and secondary education. Washington, DC: National Center for Education Statistics.

Peeraer, J., \& Van Petegem, P. (2012). The limits of programmed professional development on integration of information and communication technology in education. Australasian Journal of Educational Technology, 28(6), 1039-1056.

Pierson, M. (2001). Technology integration as a function of pedagogical expertise. Journal of Research on Computing in Education, 33(4), 413-430.

Radikal (2012). Dinçer: FATİH Projesi'nin maliyeti 8 Milyar TL. (Erişim: 02.01.2016), http://www.radikal.com.tr/egitim/dincer-fatih-projesinin-maliyeti-8-milyar-tl$1088902 /$

Roblyer, M. D. (2006). Integrating educational technology into teaching. Upper Saddle River, NJ: Merrill Prentice Hall.

Sparks, D., \& Loucks-Horsley, S. (1989). Five models of staff development. Journal of Staff Development, 10(4), 40-57.

Spector, J. M. (2001). An overview of progress and problems in educational technology. Interactive educational multimedia: IEM, (3), 27-37.

Toledo, C. (2005). A Five-Stage Model of Computer Technology Infusion into Teacher Education Curriculum. Contemporary Issues in Technology and Teacher Education, 5(2), 177-191.

Tondeur, J., Krug, D., Bill, M., Smulders, M., \& Zhu, C. (2015). Integrating ICT in Kenyan secondary schools: an exploratory case study of a professional development programme. Technology, Pedagogy and Education, 24(5), 565-584.

Unger, K. L., \& Tracey, M. W. (2013). Examining the factors of a technology professional development intervention. Journal of Computing in Higher Education, 25(3), 123-146.

Uslu, Ö., \& Bumen, N. (2012). Effects of the professional development program on Turkish teachers: Technology integration along with attitude towards ICT in education. TOJET: The Turkish Online Journal of Educational Technology, 11(3).

Wang, S. K., Hsu, H. Y., Reeves, T. C., \& Coster, D. C. (2014). Professional development to enhance teachers' practices in using information and communication technologies (ICTs) as cognitive tools: Lessons learned from a design-based research study. Computers \& Education, 79, 101-115.

Yıldırım, A., \& Şimşek, H. (2006). Nitel araştırma yöntemleri (6. baskı). Ankara: Seçkin Yayıncilik.

Yıldırım, Ö., Kurşun, E., \& Göktaş, Y. (2015). Bilgi ve iletişim teknolojileri konusunda yapılan hizmet içi eğitimlerin niteliğini etkileyen faktörler. Eğitim ve Bilim, 40(178). 